\title{
The Fading Away of Frontiers during Neoliberalism \\ Work, Crime and the Law among Argentinean Youth
}

\section{Gabriel Kessler}

Conicet-Universidad Nacional de La Plata (UNLP) - La Plata, Argentina.

gabriel_kessler@yahoo.com.ar

\begin{abstract}
The emergence of a segment of the population that alternates legal and illegal acts to survive during the nineties, thus establishing a special relationship with the law, is analyzed in this article. It shows the emergence of a sector of the population that, neither worker nor "professional criminal," survives on the basis of a combination of legal and illegal activities in a period in which work was scarce. Following a sector containing statistical data, the relationship between crime and work is analyzed, followed by a section on the rationale underlying the young people's acts, the symbolic space occupied by the law, peer group relations and, finally, relations with the police.
\end{abstract}

Keywords: Youth crime. Juvenile justice system. Precarious work. Argentina. 


\section{Introduction}

T t has become increasingly commonplace to observe out that fear Lof crime emerged as a prominent feature of Argentinean public consciousness from the mid-1990s onwards. Such assertions however overlook the fact that opinion polls throughout the mid to late 1980s consistently reported that some 50 percent of the population of the country felt insecure during this period. To a large extent, this state of affairs was due to contingent historical factors, insofar as rumors abounded following the collapse of the military dictatorship that the defunct regime's redundant agents of repression had begun dedicating themselves to kidnapping, theft, and other forms of criminality rather than torture and subjugation. Such ideas were fuelled by sensational media reporting provoking successive waves of "moral panic" (see Cohen, 1972). First there were the "taxi robberies", then the "express kidnappings", and after that the "spidermen" grappling into apartment blocks, and the list goes on and on... The fear of rogue ex-agents of the dictatorship dissipated by the early 1990s, however, and fear of crime became increasingly associated with the unemployment and impoverishment linked to the profound economic recession that began to affect the country, and which eventually culminated in the notorious politico-economic crisis of 2001 (see Kessler, 2009).

Just as fear of crime in the 1980s was associated with a particular category of social actors, so the insecurity of the 1990s came to be linked to a specific subject, namely youth, and more specifically, unemployed young men from low-income neighborhoods. Unlike the militarily trained criminals of the past, however, these are widely considered to be less "professionals" - because thought to be more often than not acting under the influence of drugs - and therefore more dangerous. ${ }^{1}$ This

\footnotetext{
1 The term most clearly depicting this particular imagination is "pibes chorros", an expression that means something akin to "rip-off kids", and which is used to describe a subset of youth who have their own style of dress and their own music - the cumbia villera - whose lyrics unapologetically chronicle their delinquency.
} 
notion has had dramatic consequences for the juvenile justice system in Argentina, most dramatically illustrated by the growing number of "quick trigger" human rights abuses by the Police, especially in relation to low-income youth. These have been further fuelled by the government's "zero tolerance" reaction to youth violence, and the implementation of repressive policies that have enjoyed the support of an overwhelming majority - albeit not all - of the political spectrum, as well as much of wider society, as was the mass demonstrations that rocked the country following the kidnapping and assassination of an upper middle class youth called Alex Blumberg in 2004 spectacularly reflected. Yet the true nature of the relationship between crime and youth in Argentina is arguably highly misunderstood, and such repressive policies completely miss their target.

Part of the problem is that there has been a conspicuous absence of empirically grounded social science research on the causes and nature of crime in Argentina. One obstacle to this has been the widespread conviction that the explanation for rising crime is relatively straightforward. Delinquents are perceived as rational, cost-benefit calculating homo economicus, who turn to illegal means of economic survival as legal employment opportunities decline. Youth from lowincome communities are considered especially vulnerable, particularly considering the widespread failure of the Argentinean education system to provide them with marketable skills. The research I present here highlights how this view constitutes a gross over-simplification. ${ }^{2}$ What I argue instead is that the broader socio-economic conditions that have characterized Argentina since the 1990s have led to a segment of

2 This research was conducted as part of a larger project (see Kessler, 2004), and was based on field work carried out in stages between September, 1999 and March, 2002 in the city and the Province of Buenos Aires. Approximately 100 interviews were carried out with 70 youth (60 males and 10 females) under 25 who had committed armed robbery. The greater number of males is due to the fact that the majority of offenders are young men. Interview were also carried out with ten offenders over the age of 40, most of whom were "retired" thieves, hooligans, or drug dealers. Finally, interviews were also conducted with 30 "institutional" informants such as lawyers, psychologists, social workers, policemen, and judges, as well as relatives and friends of offenders. 
the country's juvenile population combining legal and illegal means to survive, thereby constituting them as "amateur delinquents" with a particular relationship to the law. I begin exploring the relationship between crime and work, describing in particular the emergence of a "procurer rationale" among Argentinean youth, and how this governs youth delinquency. I then follow this with a consideration of the way that the rule of law is perceived. A final section considers the various forces currently attempting to define the public security agenda in Argentina. This article is based on a research carried out during the socalled "neoliberal period" (from 1990 to 2003). Therefore the hypotheses and ideas presented in the following pages are above all valid for that period. After 2003 I did a new research in the "pos-neoliberal period". I pondered the common points and the differences between the two periods in others papers (e.g. Kessler 2013).

\section{Crime, youth, and employment in Argentina}

According to official government statistics, the number of crimes committed in Argentina doubled during the 1990s, increasing from 560,240 in 1990 to 1,062,241 in 1999. Expressed in terms of the number of criminal acts reported for every 100,000 inhabitants, the crime rate therefore went from 1,722 in 1990 to 2,904 in 1999. The corresponding figures for the country's capital city, Buenos Aires, are even higher: 2,046 per 100,000 in 1990 and 6,301 per 100,000 in 1999. Although homicides have increased during the course of the past two decades, from an average rate of 3.9 per 100,000 in the $1980 \mathrm{~s}$ to 4.8 per 100,000 inhabitants in the 1990 s, over 70 percent of all crimes committed in Argentina are property crimes (DNPC, 2000). The latter are often particularly associated with youth; over 90 percent of those charged with a property crime in Buenos Aires were young men under the age of 25 . The number of youth passing through the Argentinean penal system has also increased dramatically (Bonaldi, 2002). By 2000, 20 percent of all sentences passed involved defendants 
between 18 and 20 years of age, and in 1999, 58\% of the minors accused of property crimes stated they were attending school (Guemureman, 2002). Not surprisingly, perhaps, the average age of the Argentinean prison population dropped from 31 years of age in 1984 to 21 years of age in 1994 (Citara, 1995). This has occurred during a period of unprecedented economic hardship, marked in particular by high levels of unemployment and rising inequality, and many researchers have made the case that there is therefore likely to be a relationship between these two trends. Navarro (1997), for example, suggests that rising unemployment can be directly correlated with rising criminality, while Cerro and Meloni (1999) contend that inequality in income distribution is the determining factor, the latter even going so far as to suggest that every 10 percent increase in inequality can be correlated with a 3 percent rise in the crime rate. Such interpretations are arguably marred by two basic flaws, however. The first is the classic methodological confusion of correlation with causality, and presupposing that it is the unemployed who are committing the crimes, something that the statistics do not bear out. Certainly, of the 70 youth who had committed a crime interviewed for this research, only 37 percent were unemployed, while 45 percent said that they were working part-time or irregularly, and 16 percent were working full time.

The second flaw is more epistemological in nature, insofar as analyses that link unemployment with crime tend to draw on North American and Western European experiences, whereby long-term unemployment is correlated with the turn to crime. Contrarily to North American and Western European labor markets, unemployment in 1990s Argentina tended to be short-term. What did change, however, was the underlying nature of the labor market, as jobs became increasingly low-paid and precarious, offering minimal salaries and no benefits, and often lasting only just a few months at a time. This labor market transformation led to a fundamental change in employment patterns, with new entrants into the labor market in particular developing unstable job trajectories 
characterized by frequent changes from one low-paid, short-term precarious job to another, with short periods of unemployment in between. The kinds of jobs associated with the youth interviewed for this research were occupations such as being office or delivery boys, cleaning and maintenance workers, salespersons in small shops, short-haul truck loaders, babysitters, or car washers, among others. When the last three jobs of individuals could be compared, it turned out that the average income derived from the first was 400 Argentine pesos, 305 pesos from the second, and 299 pesos from the third. The duration of the jobs similarly declined from 20 months for the first job, compared to 10 months for the second and third. It is this new type of employment pattern rather than unemployment per se that has had particular consequences for crime in Argentina.

\section{Crime, employment, and the "procurer rationale"}

The changing nature of the labor market has had critical ramifications for the way in which work is conceived by contemporary Argentinean youth, particularly in low-income communities. Contrarily to their parents, who entered the job market with expectations of stable, long-term employment, they now assume that they will inevitably experience job insecurity. This normalization of labor instability has had critical sociopsychological consequences. Upward mobility through a "meaningful occupation" has become difficult to imagine, and the notion that a job is a source of status, values, and a living wage has been superseded by the idea that a job is simply a means of obtaining money. I define this change as a transition from a "worker" to a "procurer rationale" (see Kessler, 2004), with the key difference between the two perspectives being the way that the source of income is legitimized. In the "worker rationale", legitimacy resides in the origin of income: it is the fruit of "honest" labor in a socially-recognized, respectable occupation. The procurer's source of legitimacy, however, is to be found, not in the origin of the money but in its utilization to satisfy needs. In a word, any source 
of money, regardless of means, is regarded as legitimate so long as it is used to satisfy a need. The scope of legitimate needs goes far beyond basic ones such as food, for example, but includes anything considered a need by the individuals themselves: paying a utility bill, buying clothes, beer, or marijuana, celebrating a friend's birthday, or even going to see the Iguazú Falls (a major tourist attraction in Argentina).

This transformation in the way work is perceived has led to lowincome youth in Argentina increasingly regularly combining - both simultaneously and consecutively - legal and illegal income-generating activities. Certainly, the youth interviewed for this research all combined legal employment with criminal activities, for example. In some case they resorted to crime whenever they were out of work, but in most legal and illegal income-generation occurred concurrently. Most earned low incomes through precarious legal jobs, which they supplemented through begging, demanding "toll" (obstructing foot traffic on a neighborhood street and demanding money to pass), mugging, or engaging in petty robbery, for example. A similar fact was analyzed in the case of Brazil by V. da Silva Telles (2009), who defined this passage from legal to illegal as "lateral mobility". The distinction between legal and illegal incomegeneration had largely faded away as a result, with the choice of resorting to one or the other largely dependent on the opportunities that present themselves at any given point in time. Indeed, the "procurer rationale" can be said to be intricately linked to an informal Argentinean cultural code known as "ventajeo", that is to say trying to "take advantage" of people and situations, by any means possible. This is a modus operandi that implies quick-thinking and anticipating the moves of others - an analogy can perhaps be made here with duels in cowboy movies, the first one to draw wins - and is therefore intimately underpinned by a sense of immediacy.

The "procurer rationale" is to this extent very different to the economic analysis of crime famously put forward by Gary Becker (1968). This theory supposes the existence of rational actors, homo economicus who carry out cost-benefit analyses before deciding whether 
or not to commit a crime. In other words, they will consider factors such as unemployment or low income - both of which are seen as increasing the likelihood of committing a crime - against the chances of being caught and the nature of potential punishment - increased policing and longer sentences are both thought to reducing the attractions of crime in order to come to a logical decision. In order to rationally weigh up the costs and benefits of an eventual criminal act, the potential delinquent must be able to foresee beyond the act itself and have a sense of the potential consequences that might be suffered, however. This was clearly not something that came to the mind of the youth interviewed for this research, whose intention was very obviously to fulfill an immediate need, explaining their crime in terms such as: "I needed money and went out to look for it" or "I had a job and needed money to get to it, so I went out to steal the money for the bus", for example. Indeed, much of the criminal activity carried out by the youth interviewed for this research was clearly highly contingent. One group of youth for example explained their mugging an old lady by saying "we were there, and we saw an old lady pass, and we decided to go for it", something which although arguably involving a (limited) calculation of risk - since "an old lady" is in many ways the epitome of an easy victim unable to offer resistance also highlights how their action was unpremeditated, improvised, and instantaneous. The fact that they chose a victim with obviously little to offer further highlights the spontaneous nature of such action. ${ }^{3}$

\footnotetext{
Most youth crime in Argentina is committed in groups rather than by individuals. A distinction has to be made in this respect between "proveedores", or "procurers", and "barderos", or "disrupters", however. Although both groups engage in criminal activity, they do so for very different motives. "Procurers" commit crimes for purely instrumental motives, while "disrupters" commit crimes as part of a series of group activities that are affirmative of the peer group. Playing loud music at siesta time or sitting on the corner and bothering ("bardear") passersby are classic examples of "bardo", as is group robbery, which is a group activity which has important expressive objectives. Acts are decided on and carried out by the group, and, above all, the profits of criminality are consumed collectively - for going out, eating out, and buying drinks or drugs. "Procurers" tend to split the profits between themselves and then spend the money as they individually see fit. It is important to note, however, that neither "procurers" nor "disrupters" are "gangs", in the sense described in the well-established literature on the phenomenon in the United States, or the more recent one on Central America. Neither type of group displays much in the way of a strong identity, cohesion, territorial associations, hierarchies, initiation rites, and so on.
} 
At the same time, this isn't to say that delinquent youth were not subject to certain codes. This was especially evident in relation to the money obtained from crime. Money, as is not neutral, and when these youth combined legal and illegal activities, a "two-money" system tended to emerge, in which the "hard" money earned on the legal job was used for important expenses like helping out at home or commuting to and from work, while the "easy" money acquired through crime was used for non-essential expenses such as a night on the town, beer, namebrand sneakers, or gifts, among others. This "two-money" system was a sign that the fading away of the frontier between legal and illegal activities was not complete; certain distinctions persisted, in this case, the dual system for spending money according to its origin that clearly differentiated legal activities from illegal ones. There also arguably existed a widespread difference in the value accorded to different types of income-generation. Formal work was normatively considered "better" than crime, for example; there was thus no evidence of a sub-cultural construction diametrically opposed to the mainstream. Beyond this normative discourse, however, the relationship that the youth interviewed had to work emerged as clearly highly instrumental. Their experiences of jobs insecurity and instability offered no chance for learning a trade or acquiring specific job skills, and furthermore made constructing any kind of workplace identity - whether based on a particular trade, trade union, or company - difficult. In the absence of the skill-generating and socializing aspects traditionally associated with the world of work, employment became merely instrumental to the youth we interviewed, a way to procure money among many others, including crime.

\section{The fading away of the law}

The blurring of the boundary between legal and illegal economic activity has had ramifications beyond the world of work. In the not-so-distant past, the workplace was a terrain in which social and labor rights were experienced (Jelín, 1996). Part of the social training provided by a job 
consisted in learning about and having recourse to laws governing the relationship between employer and employee, limiting exploitation, and mediating conflicts and distribution disputes involving wages and benefits. Argentina has also long had laws determining compensation in the case of hardship, an accident or sickness. Such laws clearly not being applied to the overwhelming majority of youth interviewed, who reported being thrown out of jobs without being paid or even being told why they were fired, being sent back home without medical attention after work-related accidents, and so on. Some even worked without knowing how much they were to earn, and many stressed the highly informal nature of their - generally unwritten - work arrangements. The working world as a place governed by the rule of law had in other words been replaced by a workplace that appeared to be governed exclusively by the will of the employer, unchecked by any sort of predictable rules and regulations.

Perhaps not surprisingly as a result, many of the youth interviewed during the course of research clearly failed to perceive the law as a mediating factor that could legitimately intervene in private conflicts. One youth for example could not understand why, after having been caught by the Police following a robbery, he was charged after saying that he was sorry and returning what he had stolen intact to his victim. He was even more indignant when talking about the neighbor who had denounced them to the police, saying: "I don't understand, if I didn't steal from him, why did he have to get involved?". It should be noted, however, that this fading away of the idea of a rule of law did not imply the disappearance of moral judgments on the part of these youth. During the course of one interview, a youth recounted how whilst robbing a house and holding up its inhabitants at gunpoint, he had placed his gun to the head of one of the children in order to make the father confess where he had hidden his money. The father denied having any money until the youth placed the gun to his head, at which point he very rapidly told him where it was. The youth couldn't hide his fury, and 
indignantly exclaimed: "what kind of father is that, his own life is more important to him than his children's! I should have killed him!". Instead, he stabbed a knife into the father's thigh before leaving, "to teach him a lesson". This youth's indignation and his moral judgment would be incomprehensible without taking into account the absence of any notion on his part of the existence of a rule of law that he himself was breaking. In many ways, he had, in fact, become a law unto himself. Certainly, the possibility of an external agent intervening in private conflicts was diluted to such a degree that any reference to the State as a party to their destiny was incomprehensible to the youth interviewed for this research. When, after being asked to describe their - generally harsh - economic situation, they were asked what they saw as the State's potential role in solving their problems, the interviewed youth often didn't grasp what was meant. "The state of what?", they would reply perplexedly, as if I had asked them a completely nonsensical question. More generally, it was striking how none of the state institutions routinely affecting the lives of these youth, such as school or the Police, for example, emerged as representing a legitimate source of authority for these young people. ${ }^{4}$ The Police, in particular, was simply seen as an(other) armed group, albeit better armed and trained than the others occupying their local space, which is why it was greatly feared, although more because of the possibility of dying or being hurt if one fell into the hands of the Police rather than because they would charge them and ensure that they be tried in court. Certainly, Police violence against youth is a nationwide concern in Argentina. In the last two decades there have been a number of notorious cases in which youth were killed while in police custody. Torture and harassment by the police are a daily occurrence in low-income neighborhoods, particularly in Buenos Aires province. At the same time, however, Policemen were not strangers to the youth we interviewed; they were often neighbors, or came from the

4 Obviously, Argentina's history of dictatorship can also be seen as having contributed to this discrediting of the State within wider society. 
same neighborhoods, and occasionally they were even relatives. Indeed, some of the youth interviewed actually stated that in the future they would stop robbing and work as Policemen, perceiving that the skills and behavior required were quite similar to the ones that they were acquiring through crime.

\section{Conclusion}

The rise of the procurer rationale during the nineties has had critical ramifications for the operation of juvenile justice in Argentina. The idea persists among experts that a crime hides a particular personalitytype or social experience - such as for example, social marginality or unemployment - and that it is this that produces the youthful delinquent. The fading away of frontiers between work and crime has placed in doubt both the existence of a particular identity when a crime is committed and the idea that committing a crime necessarily means consistently leading a life of crime. Crime is not a sub-cultural behavior, but rather has become part of a mainstream action repertoire for large swathes of the population in Argentina in the end of the last century. The spheres of work and crime, formerly considered mutually exclusive, were intimately linked within the country's neoliberal political economy, and this had led to a particular socialization process in which the old frontiers between activities no longer existed. In this sense, a juvenile justice system predicated on a strict division between criminality and morality, as is the case in Argentina, was bound to fail in its rehabilitative attempts, while at the same time, the intimate interrelating of crime and low-income status and job precariousness also meant that calls for punitive actions against the poor become ever more difficult to resist. As I said, these findings were the outputs of a research carried out during the neoliberal era. But Argentina, as others Latin American countries, has been undergone a "post-neoliberal era" from 2003 to the present. Most of social variables have strongly improved in the region. In special, social inequality dropped but crime did not. That is a common situation 


\section{in Argentina, Brazil, Uruguay, Ecuador, Bolivia and Venezuela. Thus a big question remains still unanswered: continuities and changes between the two periods.}

\section{References}

BECKER, Gary. Crime and Punishment: an Economic Approach. Journal of Political Economy, v. 4, n. 76, 1968, p. 169-217.

BONALDI, Pablo. Evolución de las muertes violentas en la Argentina, 1980-1999. In: GAYOL, Sandra; KESSLER, Gabriel. Violencias, delitos y justicias en la Argentina. Buenos Aires: UNGSManantial, 2002.

CERRO, Ana María; MELONI, Oscar. Análisis económico de las politicas de prevención y represión del delito en la Argentina. Córdoba: EUDECOR, 1999.

CITARA, Rodolfo. El Plan penitenciario bonaerense. Revista del Servicio Penitenciario Bonaerense, n. 8, 1995, p. 56-69.

COHEN, Stanley. Folk devils and Moral Panics: The Creation of the Mods and Rockers. London: MacGibbon and Kee, 1972.

GUEMUREMAN, Silvia. La contracara de la violencia adolescente-juvenil: la violencia publica institucional de la agencia de control social judicial. In: GAYOL, Sandra; KESSLER, Gabriel. Violencias, delitos y justicias en la Argentina. Buenos Aires: UNGS-Manantial, 2002.

JELÍN, Elizabeth (Ed.). Vida cotidiana y control institucional en la Argentina de los 90. Buenos Aires: Grupo Editor Latinoamericano, 1996.

KESSLER, Gabriel. Sociología del delito amateur. Buenos Aires: Paidós, 2004.

KESSLER, Gabriel. El sentimiento de Inseguridad. Sociología del temor al delito. Buenos Aires: Siglo XXI, 2009.

KESSLER, Gabriel. Ilegalismos en tres tiempos. In: CASTEL, Robert; KESSLER, Gabriel; MERKLEN, Denis, MURAD, Numa. Individuación, Precariedad y Riesgo ¿Desinstitucionalización del presente? Buenos Aires: Paidós, 2013.

NAVARRO, Lucas. En Argentina el crimen paga. Novedades Económicas, n. 196, 1997. p. 17-28.

SILVA TELLES, Vera. Nas dobras do legal e ilegal: ilegalismos e jogos de poder. Revista Dilemas, n. 5-6, 2009, p. 97-126.

Received: September 08, 2014.

Accepted: November 25, 2014. 